\title{
Effects of increased red cell mass on subclinical tissue acidosis in hyaline membrane disease
}

\author{
Edmund F La Gamma, Alfred Krauss, Peter A M Auld
}

\begin{abstract}
Aim-To determine whether there are subclinical deficits in oxygen delivery in ventilated premature neonates.

Method-Ventilated premature neonates weighing less than $1500 \mathrm{~g}$, who were transfused for anaemia or who were given colloids for clotting abnormalities (or oedema), were haemodynamically monitored during the first week of life. Calf muscle surface pH (tpH) was measured in conjunction with peripheral limb blood flow by occlusion plethysmography.

Results-Packed red blood cell transfusions corrected a subclinical regional tissue acidosis (low tpH) without affecting arterial pH or limb blood flow. This observation also correlated with an increase in regional oxygen delivery. The data were also suggestive of a pattern of pathological, supply dependent, oxygen delivery and are similar to other observations made in adults with adult respiratory distress syndrome.

Conclusions-Packed red blood cells increase regional oxygen delivery and tissue surface pH. In contrast, colloid infusion provided no substantial cardiovascular or metabolic benefit to these patients and should be avoided when oxygen delivery is at issue and when there may be leaky pulmonary capillaries.

(Arch Dis Child 1996;75:F87-F93)
\end{abstract}

Data from this paper were presented in part at the Society for Pediatric Research, Washington, DC in 1978 (Abstract 987) and in 1980

(Abstract 1065)

Division of Newborn

Medicine,

Department of

Pediatrics,

University at Stony

Brook,

Stony Brook, New York

11794-8111

USA

E F La Gamma

The Perinatology

Center,

New York

Hospital-Cornell

Medical Center,

New York, USA

A Krauss

P A M Auld

Correspondence to: Dr E F La Gamma.
Keywords: anaemia, critical oxygen consumption, hyaline membrane disease, colloid, packed red blood cells.

In acutely ill very low birthweight preterm neonates $(<1500 \mathrm{~g})$ blood volume falls soon after birth as a result of frequent blood sampling and large evaporative water losses. ${ }^{12}$ Under these circumstances, haemoglobin and haematocrit concentrations will not reliably depict the total body capacity to deliver oxygen as secondary shifts in body fluid compartments and a change in the size of capacitance vessels may result in "normal" values even after substantial losses of red cell numbers. ${ }^{3-5}$ In this regard, the absolute red cell mass (RCM) (a quantity; haematocrit $x$ blood volume) is thought to reflect better the actual diminished oxygen carrying capacity. In fact, when the value for RCM is multiplied by cardiac output, total body oxygen delivery can be determined and used as a predictor of survival. . $^{5-7}$

The clinical impact of the difference between RCM and haematocrit is of concern because a compensatory redistribution of regional blood flow will also ensue if systemic oxygen delivery is inadequate. ${ }^{8-10}$ Any maldistribution of peripheral blood flow will further exaggerate subclinical organ deficits in oxygen delivery which may still go unrecognised in the presence of normal systemic haemodynamics. ${ }^{9-11}$ Fortunately, this maladaptive redistribution of regional blood flow can be identified in adults by measuring intramucosal gut $\mathrm{pH}$ (gut tonometry), ${ }^{12}$ or by determining muscle surface $\mathrm{pH}$ (tissue $\mathrm{pH}$ electrodes). ${ }^{14-18}$

Knowledge of low intramucosal tpH and deficits in regional $\mathrm{O}_{2}$ delivery have been correlated with survival in adults. ${ }^{19-21}$ Whether similar information will prove therapeutically or prognostically useful in sick preterm neonates is yet to be determined. Furthermore, as none of the current recommendations for assessing the need for red blood cell transfusion in very low birthweight neonates is based on actually measuring oxygen delivery to any particular vascular bed, $22-25$ we examined this issue in 33 of our ventilated VLBW patients.

\section{Methods}

During July 1978 through June 1980 , VLBW neonates ( $<1500 \mathrm{~g}$ at birth) were selected for study from the general population of patients admitted to the Perinatology Center of the New York Hospital-Cornell Medical Center if their principal diagnosis was hyaline membrane disease (HMD) and if they required oxygen and mechanical ventilation. Parents of those patients meeting these criteria were approached to obtain consent for placement of a tissue $\mathrm{pH}$ electrode ( $\mathrm{tpH}$; equivalent "muscle surface" $\mathrm{pH}$ electrode) ${ }^{14-18}$ and for measurement of peripheral blood flow by occlusion plethysmography. The study protocol was approved by the New York Hospital Institutional Review Board concerning human investigation. The procedure was performed solely for research purposes on the assumption that tpH would reflect arterial blood $\mathrm{pH}$ and would thus avoid some blood sampling when used in conjunction with transcutaneous oxygen and carbon dioxide electrodes.

All patients were managed under radiant warmers for the duration of this study. Endotracheal tubes were placed on admission if $\mathrm{FIO}_{2}>0.40$ was necessary to keep the $\mathrm{PaO}_{2}>50 \mathrm{~mm} \mathrm{Hg}$, or for a $\mathrm{PaCO}_{2}>45-50$ $\mathrm{mm} \mathrm{Hg}$. Ventilator settings were then adjusted to keep the arterial blood $\mathrm{pH}$ between 7.30 and 7.45, the $\mathrm{PaCO}_{2}$ between 30 and $45 \mathrm{~mm} \mathrm{Hg}$, 
and the $\mathrm{PaO}_{2}$ between 50 and $70 \mathrm{~mm} \mathrm{Hg}$. Antibiotics (ampicillin and gentamicin) were administered for at least 72 hours after birth in all patients or until sampled body fluid cultures showed no growth. Parenteral fluid intake was adjusted to maintain the urine output at 1 to 2 $\mathrm{ml} / \mathrm{kg} /$ hour and electrolytes were added to it to maintain serum concentrations in the normal physiological range. Umbilical catheters were placed on postnatal day 1 to permit monitoring of blood pressure, for blood sampling every 2 to 4 hours, and for infusion of fluids. All patients were maintained on a nil by mouth regimen throughout the duration of study.

During the course of this study, routine neonatal intensive care interventions were monitored for their impact on $\mathrm{tpH}$ during the first seven days after birth. Decisions to transfuse blood products were made by the neonatologist who was directly responsible for the overall medical management of the patient independently of the monitoring protocol used during transfusions. When transfusions were administered, monitored data included observations on the effects of administration of either packed red blood cells ( 10 to $15 \mathrm{ml} / \mathrm{kg} ; 10$ to $20 \%$ of estimated blood volume of $80-90$ $\mathrm{ml} / \mathrm{kg}^{12}$ for a haematocrit below 35 to 40 (customary clinical practice at the time of study) or for colloid infusion using fresh frozen plasma (FFP, $10 \mathrm{ml} / \mathrm{kg}$ ) or albumin ( $5 \mathrm{ml} / \mathrm{kg}$ for $25 \%$ or $15 \mathrm{ml} / \mathrm{kg}$ for $5 \%$ product). Colloid solutions were given for evidence of clotting abnormalities (FFP), to replace chest tube drainage (FFP or $5 \%$ albumin), or to assist in fluid mobilisation in the presence of peripheral oedema ( $25 \%$ albumin). These interventions remain within currently accepted therapeutic guidelines today. ${ }^{822-25}$

For 1 hour before, and for 1 hour after, transfusion, heart rate, blood pressure (umbilical arterial catheter, Hewlett-Packard transducers plus the HP Clinical Monitoring System), respiratory rate (thoracic impedance), and tissue surface $\mathrm{pH}$ were each recorded on a paper strip chart recorder (Electronics for Medicine, Indianapolis, USA). The continuous clinical data were sampled for 5 minutes every quarter of an hour and averaged to represent the entire hour for each individual transfusion in each patient. An arterial and venous (inferior vena cava) blood gas and a peripheral haematocrit were simultaneously sampled immediately before starting a transfusion and at the conclusion of the hour following the transfusion. Peripheral blood flow was measured every 15 minutes for 1 hour before and immediately following transfusions; values were averaged for each monitored variable before and after transfusion.

Sterile, glass tipped, flexible lead tissue surface $\mathrm{pH}$ electrodes were inserted and calibrated in vivo using the method of $\mathrm{La}$ Gamma et al ${ }^{18}$ to measure muscle surface $\mathrm{pH}$. In brief, a small skin puncture (2 to $3 \mathrm{~mm}$ in length using a No 11 scalpel) was made midway down on the medial aspect of the skin of the calf with the use of a local anaesthetic.
The 21 gauge tpH electrode (Microelectrodes Incorporated, Massachutsetts, USA) was inserted between the skin and the muscle surface after forming a subcutaneous pocket by blunt dissection with a sterile probe. Calibration of the $\mathrm{pH}$ meter (Corning Analytical $\mathrm{pH}$ Meter, Corning, New York, USA) and electrodes were accomplished by interposing a sterile buffer between the patient and the electrode at the wound site and also at a mucosal surface. The two site and two $\mathrm{pH}$ electrode calibration allowed for in vivo recalibration once daily and at the conclusion of the monitoring period to correct for any drift of the $\mathrm{Ag} / \mathrm{AgCl}$ skin electrode used to complete the circuit. ${ }^{18}$ This method is typical for calibrating oesophageal $\mathrm{pH}$ electrodes currently in use today (operating instructions for model MI506/508 Esophageal pH Meter, Miecroelectrodes Inc., Londonderry, New Hampshire, USA). In our series and in other reports, no complications of this procedure have ever been noted-for example, bleeding, infection, additional trauma-using this technique as, in effect, it is no different than inserting a 21 gauge needle subcutaneously.

Limb blood flow was measured in the in the lower limb contralateral to the previously placed tpH electrode. The method of occlusion plethysmography was used in most patients, as adapted by Krauss $e t a l^{6}$ or the simpler method of impedance plethysmography, as described by Costeloe et al. ${ }^{27}$ These two methods provide nearly identical measurements of limb blood flow per $100 \mathrm{ml}$ of limb tissue in newborn babies in our hands and as reported by Costeloe. ${ }^{27}$ Results obtained with both methods also agreed favourably with those of other investigators. $^{2728}$

Before and after transfusions, an index of arterial oxygen $\left(\mathrm{CaO}_{2}\right)$ and venous oxygen $\left(\mathrm{CvO}_{2}\right)$ contents was calculated in individual patients as follows: (haematocrit/3) $\times$ (\% saturation) $\times\left(1.35 \mathrm{ml} \mathrm{O}_{2} / \mathrm{g}\right.$ haemoglobin). Dissolved $\mathrm{O}_{2}$ was considered to be negligible and was not accounted for. Banked adult blood has 2,3 diphospoglycerate (2,3-DPG) concentrations roughly equal to those circulating red cells from normal preterm neonates; concentrations subsequently increase several hours after infusion. ${ }^{23}{ }^{24}$ Consequently, we made no attempt to account for any presumptive improvement in oxygen transfer that may result from the increase in the in vivo percentage of adult haemoglobin, as our measurements were made in the first hour of monitoring immediately after the transfusion.

Oxygen delivery was calculated as the product of $\mathrm{CAO}_{2}$ multiplied by measured limb blood flow. Regional consumption was assessed by determining the difference between aortic and vena caval $\mathrm{O}_{2}$ contents multiplied by limb blood flow. Peripheral vascular resistance was calculated by dividing limb blood flow by the measured mean aortic blood pressure. Alveolar-arterial oxygen tension difference $\left(\mathrm{A}-\mathrm{aDO} \mathrm{O}_{2}\right)$ was calculated from the alveolar gas equation using aortic oxygen and carbon diox- 
Table 1 Effect of packed red blood cell transfusions (PRBC) on tissue pH and cardiopulmonary status (mean (SD) values)

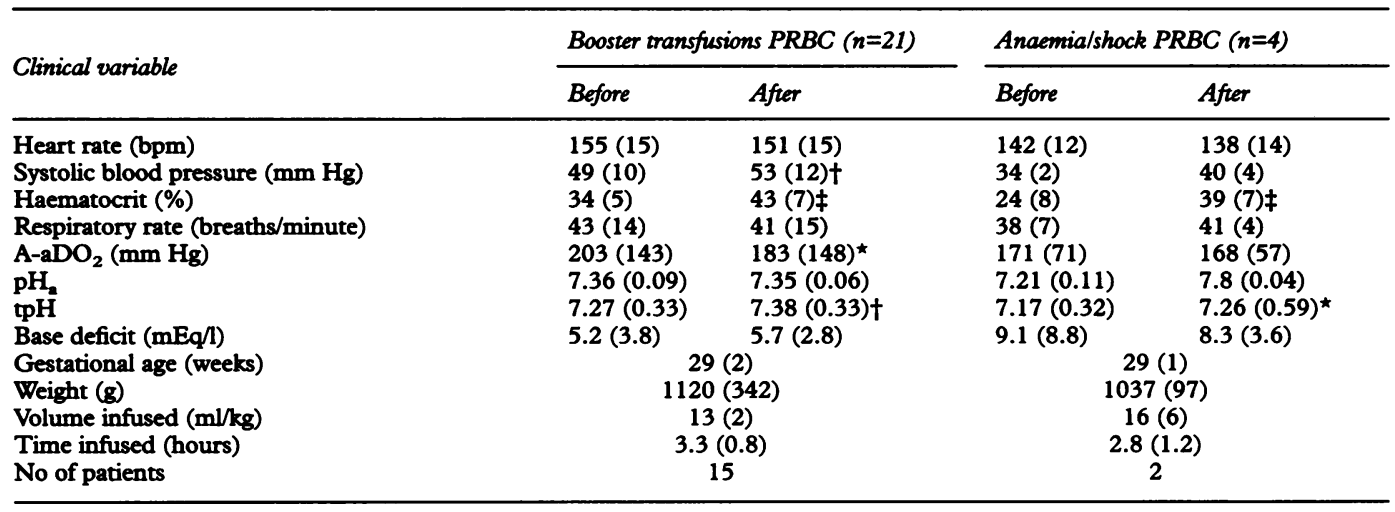

$\star P<0.05, † P<0.01, \ddagger P<0.005$.

ide tensions and assuming a water vapour pressure of $47 \mathrm{~mm} \mathrm{Hg}$.

Average values are reported in the results: the standard deviation is indicated to represent the variability of the tabulated group parameters. Grouped data before and after a transfusion were compared using the paired $t$ test.

\section{Results}

Twenty one transfusions of PRBCs were electively given to 15 ventilated, VLBW infants with an average haematocrit of 34 (5). This resulted in a significant increase in haematocrit, systolic blood pressure, and $\mathrm{tpH}$, and a fall in the $\mathrm{A}-\mathrm{aDO}_{2}$ (table 1). Arterial pHa, heart rate, and respiratory rates were unchanged. To assess better the impact of an increase in red cell mass in patients who also required volume expansion, four additional transfusions in two patients with haemorrhagic shock were analysed separately and found to respond similarly to those electively transfused for anaemia alone (table 1). In both groups of patients tissue surface $\mathrm{pH}$ was lower than arterial blood $\mathrm{pH}$ yet this difference did not achieve significance due to a wider range of values for tpH. The mean (SD) $\mathrm{FIO}_{2}$ in the anaemic group was $0.38(0.16)$ and $0.46(0.20)$ in the patients in shock.

To assess better the potentially independent effects of blood volume expansion and changes in red blood cell mass, we examined the effects of colloid infusions on monitored variables in five of the same patients studied above plus an additional nine not previously monitored for

Table 2 Effect of colloid infusions on tissue pH and cardiopulmonary status (mean (SD) values)

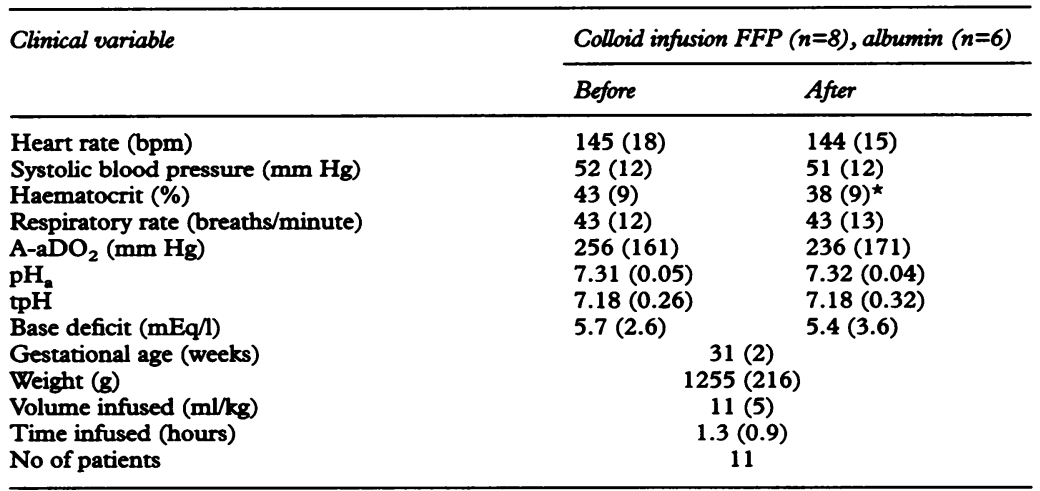

* $\mathrm{P}<0.01$; pHa: arterial blood $\mathrm{pH}$.
PRBC transfusion. Due to some differences in indications, patients receiving fresh frozen plasma (FFP) (5 for abnormal clotting, 3 for chest tube drainage) or 5\% albumin (3 for low protein, 3 for chest tube drainage) were less clinically homogenous than those in the anaemia and haemorrhagic shock groups, yet all of them had similar normal range heart rates, respiratory rates, and blood pressures before intervention (table 2). None of the colloid treated patients was anaemic (haematocrit $>35$ ) at the time of study, all had base deficits similar to those of the previous PRBC patients as well as similar $\mathrm{A}-\mathrm{aDO}_{2}$ (table 2). The only significant change in status after colloid infusion was a non-physiologically significant fall in the haematocrit from 43 (9) to 38 (9). The mean (SD) $\mathrm{FIO}_{2}$ in the colloid group was $0.59(0.25)$.

To determine whether blood flow, oxygen delivery, or both parameters, changed in response to PRBC transfusions, we measured limb blood flow during seven blood transfusions in five additional patients. Once again PRBC infusions were associated with a significant increase in blood pressure, haematocrit, and $\mathrm{tpH}$ and a fall in $\mathrm{A}-\mathrm{aDO}_{2}$ (table 3). As expected, oxygen delivery increased (table 3); however, unexpectedly, so did the base deficit, from 4.1 (3.5) to $6.1(1.9) \mathrm{mEq} / \mathrm{l}$. Other monitored variables were unchanged, although lactate (table 3 ) and catecholamine values fell (mean (SD) norepinephrine 578(433) to 508(249) and epinephrine $118(74)$ to $105(58) \mathrm{pg} / \mathrm{ml} ; \mathrm{n}=4$ patients; results courtesy of Dr Bernard Mirkin, NorthWestern University) consistent with impaired oxygen delivery and decreased cardiac work. ${ }^{29}$ Of additional interest is our observation that the PRBC infusates had a substantial lactate content and a non-physiologically low $\mathrm{pH}$ plus a large base deficit (table 4).

Measured oxygen consumption across the aorta and vena cava tended to increase after transfusion in the five patients in whom it was successfully determined both before and after the transfusion. This suggested the intriguing possibility that supply dependent oxygen consumption existed in neonates. To assess better this possibility, measured regional oxygen consumption was plotted against limb oxygen delivery for the five patients studied in table 3. Data were accumulated at various times during 
Table 3 Effect of "booster" PRBC transfusions on limb blood flow (mean (SD) values)

\begin{tabular}{|c|c|c|}
\hline Clinical variable & Before & After \\
\hline Heart rate (bpm) & $143(11)$ & $141(8)$ \\
\hline Systolic BP (mm Hg) & $50(6)$ & $55(5)^{\star}$ \\
\hline Limb flow ( $\mathrm{ml} / \mathrm{min} / 100 \mathrm{ml}$ tissue) & $11.4(4.4)$ & $11.3(5.7)$ \\
\hline Resistance & $3.6(1.8)$ & $4.3(1.7)$ \\
\hline Haematocrit (\%) & $33(4)$ & $43(6) \dagger$ \\
\hline $\mathrm{O}_{2}$ Delivery $\left(\mathrm{ml} / \mathrm{O}_{2} / \mathrm{min} / 100 \mathrm{ml}\right.$ tissue) & $1.5(0.7)$ & $2.0(0.9)^{\star}$ \\
\hline $\begin{array}{l}\mathrm{O}_{2} \text { Consumption }\left(\mathrm{ml} / \mathrm{O}_{2} / \mathrm{min} / 100 \mathrm{ml}\right. \\
\text { tissue; } \mathrm{n}=4 \text { patients) }\end{array}$ & $0.37(0.31)$ & $0.47(0.35)$ \\
\hline Respiratory rate (breaths/minute) & $43(14)$ & $38(10)$ \\
\hline $\mathrm{A}-\mathrm{aDO}{ }_{2}(\mathrm{~mm} \mathrm{Hg})$ & $259(144))$ & $234(134)^{\star}$ \\
\hline $\mathrm{pH}_{\mathrm{a}}$ & $7.35(0.06)$ & $7.31(0.01)$ \\
\hline tpH & $7.29(0.04)$ & $7.34(0.05) \dagger$ \\
\hline Base deficit (mEq/1) & $4.1(3.5)$ & $6.1(1.9)^{\star}$ \\
\hline Lactate $(\min / 1)$ & $3.1(2.6)$ & $1.9(0.5)$ \\
\hline Gestational age (weeks) & \multicolumn{2}{|c|}{$29(2)$} \\
\hline Weight (g) & \multicolumn{2}{|c|}{$1342(452)$} \\
\hline Volume infused $(\mathrm{ml} / \mathrm{kg})$ & \multicolumn{2}{|c|}{$15(1)$} \\
\hline Time (hours) & \multicolumn{2}{|c|}{3} \\
\hline No of patients & \multicolumn{2}{|c|}{5} \\
\hline No of transfusions & \multicolumn{2}{|c|}{7} \\
\hline
\end{tabular}

${ }^{\star} P<0.05, \uparrow P<0.01, \ddagger P<0.001$.

Table 4 Mean (SD) characteristics of PRBC transfused in table 3

\begin{tabular}{ll}
\hline Factor & $P R B C(n=7)$ \\
\hline pH & $6.89(0.04)$ \\
Base deficit (mEq/l) & $25(2)$ \\
Lactate $(\mathrm{mM} / \mathrm{l})$ & $5.2(1.0)$ \\
Haematocrit & $64(5)$ \\
Capilliary total protein (g/dl) & $6.1(0.8)$ \\
\hline
\end{tabular}

their hospital course and in most cases, in relation to the timing of the transfusion (figure 1). A significant but not powerful $(r=0.53, P$ $<0.05)$ linear correlation was observed without any sign of a change in slope consistent with the change to a critical $\mathrm{O}_{2}$ plateau. $^{910}$

\section{Discussion}

"Booster" packed red blood cell transfusions (increasing RCM) improved oxygen delivery and tissue surface $\mathrm{pH}$ with minimal effects on systemic haemodynamics, and without changing lower limb (peripheral) blood flow in ventilated preterm neonates with hyaline membrane

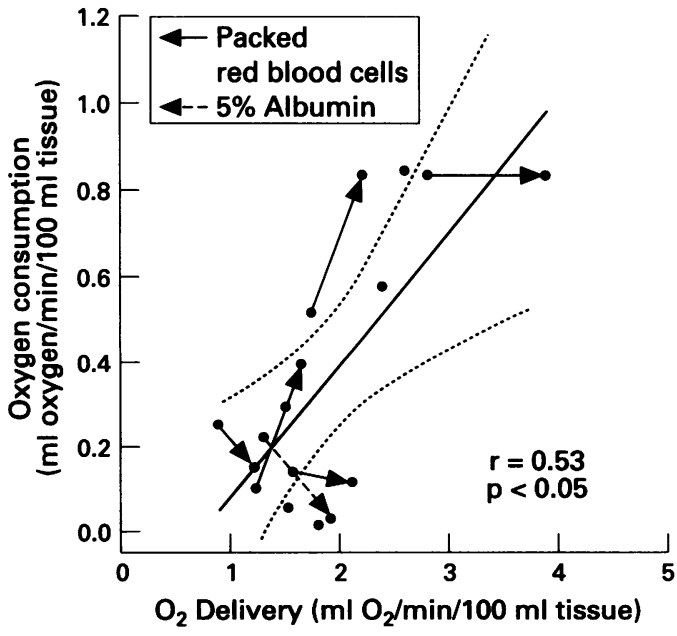

Figure 1 Results obtained from five patients who received six transfusions: five PRBC (solid arrows depict data obtained before to after infusion); one albumin (dotted arrow). In some patients an additional data point was added to illustrate the wide range of variability in this group of ventilated, sick $V L B W$ infants. no consistent clinical or cardiovascular correlation between oxygen delivery and consumption following transfusion was identified. disease (neonatal RDS) (tables 1 and 3). The observed muscle level tissue acidosis existed in the presence of a normal systemic arterial $\mathrm{pH}$, a moderate base deficit, and raised blood lactate values, suggesting that there was a subclinical deficit in organ level oxygen delivery or its utilisation, as originally hypothesised. Although other metabolic causes for tissue acidosis are possible in the acute phases of neonatal RDS, ${ }^{30-34}$ altered aerobic metabolism seems to be the most likely. ${ }^{11}$

Each of our patients received transfusions while being managed under radiant warmers. For this reason we believe it is unlikely that basal levels of oxygen consumption or cellular metabolism could have changed substantially during the study period. They could not, therefore, have accounted for the improved tpH observed under the conditions of our brief protocol (maximum of 6 hours from start to finish of data collection). On the other hand, in view of the normal oxygenation and haemodynamic status in the "booster" transfusion group (even before transfusion), we suspect that the low tpH may, in fact, be indicative of a cumulative manifestation of iatrogenic losses of RCM accumulating over the first few days after birth.

Estimates of iatrogenic blood losses average 23 millilitres per patient in acutely ill VLBW neonates (10 to $15 \mathrm{ml} / \mathrm{kg}$ ), ${ }^{1}$ making some form of empiric red cell replacement strategy commonplace $^{22-25}$ in order to maintain the RCM. Typical recommendations include infusion of banked blood when $5 \%$ or $10 \%$ of the estimated total blood volume is removed or when the haematocrit drops below 40 in ventilated patients, as in our study. ${ }^{22-25}$ These booster transfusions result in clear haemodynamic benefits such as decreased cardiac output, decreased oxygen consumption, and an increase in blood pressure. ${ }^{55-37}$ While these recommendations are based on sound physiological principles, ${ }^{8922-25}$ they address the average systemic requirements for oxygen delivery and not any particular organ specific needs. None of these approaches provides information on the critical oxygen delivery necessary to avoid anaerobic metabolism for any particular regional vascular bed..$^{10}$ Therefore, the identification of a low $\mathrm{tpH}$ in this study suggests that regional acidosis is a more common problem than ordinarily appreciated during the acute phases of neonatal RDS, and that it is not reflected in systemic indices of oxygenation. Furthermore, we suggest that iatrogenic anaemia may contribute to the maldistribution of regional peripheral blood flow and oxygen delivery that may already exist during neonatal RDS. ${ }^{1}$ Interestingly, although empiric guidelines for transfusion may not be the earliest markers for identifying the need for red cell replacement therapy, they were still quite appropriate when viewed using our method of analysis.

Additional support for a subclinical deficit in regional oxygen delivery comes from other observations, showing that a greater magnitude of improved tpH occurred following PRBC transfusions for haemorrhagic shock than for 
transfusions for anaemia alone (table 1). By comparison, colloid infusions increased neither the tpH nor changed blood pressure, heart rate, the extent of metabolic acidosis or gas exchange (table 2). Previous reports show a 1-2 $\mathrm{mm} \mathrm{Hg}$ increase in blood pressure, but no change in heart rate, and variable effects on gas exchange. ${ }^{36}{ }^{38-42}$ In contrast, both tpH and blood pressure increased after PRBC (tables 1 and 3). Taken together, and as the RCM could not possibly have increased after colloid infusion, we interpret the stable $\mathrm{tpH}$ in association with a significant fall in haematocrit (table $2)^{38}{ }^{39}$ as one of several possibilities. Either an increase in regional blood flow occurred to maintain oxygen delivery, an increase in $\mathrm{O}_{2}$ extraction, or a change in the cellular metabolic rate. Thus from our data and other reports, it seems that the only clinically relevant haemodynamic effect of infused colloid (in patients without perfusion deficits) is to cause a transient rise in colloid osmotic pressure that may help to mobilise interstitial fluids (not measured in this protocol). ${ }^{36}{ }^{38-42}$

Whether viewed as a systemic blood volume problem or a regional $\mathrm{O}_{2}$ delivery issue, red cell transfusions are needed to maintain the RCM in acutely ill ventilated VLBW neonates. However, there are infectious, thrombotic, allergic and graft versus host disease risks associated with infused blood products. ${ }^{82-25}$ Infusion of stored blood is also associated with transiently low concentrations of 2,3-diphosphoglycerate (2,3-DPG), less red cell deformability, and evidence of splanchnic ischaemia in septic adult patients as assessed by gut tonometry. ${ }^{43}$ If these problems arose in our neonates, we would have expected an adverse effect on tpH; yet $\mathrm{tpH}$ increased along with the circulating base deficit (tables 1 and 3 ). Both observations were consistent with improved cellular oxygen transport and the transient accumulation of a new acid load. Indeed, when measured, there was a substantial administration of lactate anion and titratable acid (table 4)..$^{24}$ Unlike septic adults, ${ }^{43}$ no clinically important signs of transfusion reaction, abdominal distention, or ileus were noted after PRBC transfusion.

The $\mathrm{A}-\mathrm{aDO} \mathrm{O}_{2}$ also improved after PRBC transfusions, suggesting that better intrapulmonary oxygen transfer occurred, presumably due to better matching ventilation with perfusion. Although a capillary leak syndrome might have existed in these RDS patients, ${ }^{45}$ the $\mathrm{A}-\mathrm{aDO} \mathrm{O}_{2}$ did not worsen after either colloids or PRBC (tables 1 to 3). These observations further indicated that no particular cardiopulmonary benefit could be gained by infusion of protein solutions in normotensive patients with hyyaline membrane disease, as previously noted. ${ }^{38-42}$ Alternatively, the failure to improve a low tpH in patients who received colloid infusions may stem from their cells somehow being "sicker"-for example, eight of 14 in this group had clotting abnormalities and one had bacterial growth on blood culture)(table 2)than those ventilator-dependent VLBW neonates who were electively transfused only to maintain their haematocrit at $>40$. Although we were not able to resolve this issue in our series, it may be appropriate to extrapolate certain findings from the published findings on adults and animals.

In sepsis or in adult RDS, acidosis and maladaptive oxygen delivery are believed to result from a pathological release of various endogenous cytokines that interfere with $\mathrm{O}_{2}$ utilisation and cellular metabolism even in the presence of normal levels of oxygen delivery. ${ }^{11} 3334$ In our anaemic neonates, we favour an interpretation implicating deficits in neonatal oxygen carrying capacity over a cytokine mediated effect on cellular metabolism, as limb blood flow was unchanged but tpH increased after PRBC transfusion. On the other hand, oxygen delivery alone is unlikely to be the exclusive cause of low $\mathrm{tpH}$ in the colloid group (table 2). Consequently, suspicion of a cytokine based neonatal multiorgan failure/ systemic inflammatory response syndrome cannot be entirely dismissed in ventilated VLBW neonates at this time. ${ }^{4647}$

Lastly, an unexpected finding in this series was an apparent supply dependency of oxygen consumption in the lower limb, as indicated by the absence of the expected oxygen delivery plateau in the range depicted (fig 1). Although we did not initially set out to determine these correlations, the phenomenon of supply dependent oxygen consumption is well characterised in animal models and in published findings on adult RDS. ${ }^{913} 3334$

For purposes of our comparisons, we assumed that 1 millilitre volume of neonatal lower limb tissue (calf) roughly equalled $\leqslant 1$ gram of body weight (water weight). Working with this ratio (which would tend to overestimate actual blood flow per kilogram of body weight), most of our results for oxygen consumption and delivery per $100 \mathrm{ml}$ of tissue volume (table 3 and fig 1) were at or below the minimum critical $\mathrm{O}_{2}$ delivery rate of $2.1 \mathrm{ml} \mathrm{O}_{2}$ per $100 \mathrm{~g}$ body weight (adult or paediatric tissue $^{10}{ }^{11}{ }^{35-37}$ ) the anaerobic threshold for adult patients with RDS. ${ }^{10}{ }^{11}$ Whether the putative causes of this phenomenon in the adult (cytokines, bacterial toxins, and altered metabolism $^{30-34}$ ) apply to neonates remains to be determined. In any case, in neonatal patients, organ level deficits in oxygen delivery have not been identified before. It is also apparent from our data that there is no consistent association within subjects between oxygen delivery and consumption-an increase in delivery is equally likely to accompany an increase or a decrease in consumption. Moreover, whether treatments should be administered to acutely ill neonates to increase $\mathrm{O}_{2}$ delivery to supranormal levels is unknown. ${ }^{48}{ }^{49}$ What is known is that in subacute states, evidence indicates better weight gain and less apnoea and bradycardia when the haematocrit is maintained above $30 \%$ in growing preterm neonates recovering from hyaline membrane disease. ${ }^{22-25} 3550$

In summary, we found that packed red blood cell transfusions corrected a subclinical tissue acidosis (low $\mathrm{tpH}$ ) without affecting arterial $\mathrm{pH}$ or lower limb blood flow (table 5). This observation correlated with an increase in regional oxygen delivery, as measured directly. 
Table 5 Comparison of magnitude of change in absolute value of monitored variables (mean (SEM) values)

\begin{tabular}{|c|c|c|c|c|}
\hline Clinical variable & $\begin{array}{l}\text { Booster PRBC } \\
\text { transfusion } \\
(n=21)\end{array}$ & $\begin{array}{l}\text { Anaemia/shock } \\
\text { PRBC transfusion } \\
(n=4)\end{array}$ & $\begin{array}{l}\text { Colloid infusion } \\
\text { (FFPlalbumin) } \\
(n=14)\end{array}$ & $\begin{array}{l}\text { Booster PRBC } \\
\text { transfusion }+ \text { blood } \\
\text { flow }(n=7)\end{array}$ \\
\hline Heart rate (bpm) & $-3(3)$ & $-4(5)$ & $-1(2)$ & $-2(3)$ \\
\hline $\begin{array}{l}\text { Systolic blood pressure (mm Hg) } \\
\mathrm{Limb} \text { flow (ml/min/100 ml tissue) }\end{array}$ & $+4(2) \ddagger$ & $+6(3)$ & $-1(1)$ & $\begin{array}{l}+5(2)^{\star} \\
-0.1(1.0)\end{array}$ \\
\hline Resistance & & & & $+0.7(0.4)$ \\
\hline $\begin{array}{l}\text { Haemocrit (\%) } \\
\mathrm{O}_{2} \text { delivery (nl/O } \mathrm{O}_{2} / 100 \mathrm{ml} \text { tissue) } \\
\mathrm{O}_{2} \text { consumption }\left(\mathrm{ml} / \mathrm{O}_{2} / \mathrm{min} / 100 \mathrm{ml} \text { tissue; }\right. \\
\text { n=4 patients) }\end{array}$ & $+9(1)$ & $+15(7)$ & $-5(1) \dagger$ & $\begin{array}{l}+10(1) \ddagger \\
+0.5(0.2)^{\star} \\
+0.10(0.09)\end{array}$ \\
\hline Respiratory rate (breaths/min) & $-2(3)$ & $+3(3)$ & $0(3)$ & $-5(6)$ \\
\hline $\mathrm{A}-\mathrm{aDO}_{2}$ & $-20(11)^{\star}$ & $-3(11)$ & $-20(13)$ & $-25(11)^{\star}$ \\
\hline $\mathrm{pH}_{\mathrm{a}}$ & $-0.01(0.02)$ & $+0.07(0.04)$ & $+0.01(0.01)$ & $-0.04(0.03)$ \\
\hline $\mathrm{tpH}$ & $+0.11(0.04) \dagger$ & $+0.09(0.23)^{\star}$ & $0.0(0.04)$ & $+0.05(0.01) \dagger$ \\
\hline Base deficit (mEq/l) & $+0.5(0.7)$ & $-0.8(3.7)$ & $-0.3(0.8)$ & $+2.0(0.9)^{\star}$ \\
\hline
\end{tabular}

$\star \mathrm{P}<0.05,+\mathrm{P}<0.01, \ddagger \mathrm{P}<0.001$.

The data also suggest a pattern of pathological supply dependent oxygen delivery and are comparable with similar observations in adults with RDS. Colloid infusion provided no measurable cardiovascular or metabolic benefit to these patients and we believe it should be avoided as treatment where oxygen delivery is at issue and leaky pulmonary capillaries exist.

We acknowledge the assistance of Dr J D DeCristofaro for providing helpful comments in preparing this manuscript and the Editors of this Journal for their insightful comments.

\section{Historical footnote to this report}

The data in this report were originally obtained and analysed between 1978 and 1980. When the information was originally obtained, the scope of the project was focused on determining whether a tissue surface $\mathrm{pH}$ electrode could serve as a suitable adjunct to the newly developed and recently marketed transcutaneous oxygen and carbon dioxide electrodes. Other investigators had applied the technique in adults to evaluate blood $\mathrm{pH}$ and had noted that $\mathrm{tpH}$ indeed reflected blood $\mathrm{pH}$ except during perfusion deficits when tissue $\mathrm{pH}$ was substantially lower. Thus the need to obtain a blood sample to measure blood $\mathrm{pH}$ was not abrogated. We expanded our original project specifically to address the issues of blood flow in babies by measuring limb blood flow using the technique of occlusion plethysmography. Results were obtained and published as an abstract and then were left to lie dormant as little interest remained for a new clinical device that could not distinguish between blood flow or blood $\mathrm{pH}$ without an independent measurement.

Recently, it became quite apparent to one of us (EFL) that a new understanding of the relation between oxygen delivery, oxygen consumption, and patient status had arrived in clinical medicine specifically with regard to the use of gut tonometry in patients at risk for multiorgan failure. It became obvious that we had relevant data that might be useful to our clinical colleagues and which might bear directly on the issues of "booster" transfusion as well as on controversies surrounding the use of crystalloid versus colloid infusions in premature newborns.

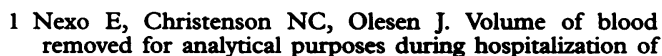
low birth weight infants. Clin Chem 1981; 27:759-61.
2 Bauer K, Bovermann G, Raithmaier A, et al. Body composition, nutrition, and fluid balance during the first two weeks of life in preterm neonates weighing less than 1500 grams. f Pediatr 1991; 118:615-20.

3 Phillips HM, Holland BM, Abdel-Moiz A. Determination of red-cell mass in assessment and management of anaemia in babies needing blood transfusion. Lancet 1986; i:882-4.

4 Wardrop CAJ, Holland BM, Jacobs S, Jones JG. Optimization of the blood for oxygen transport and tissue perfusion tion of the blood for oxygen transport and tissue
in critical care. Postgrad Med $₹$ 1992; 68:S2-S6.

5 Hudson I, Cooke A, Holland B. Red cell volume and cardiac output in anaemic preterm infants. Arch Dis Child 1990;65:672-5.

6 Russell JA, Ronco J, Lockhat D, Belzberg A, Kiess M, Dodek PM, et al. Oxygen delivery and consumption and ventricular preload are greater in survivors than in nonsurvivors of the adult respiratory distress syndrome. Am Rev Respir Dis 1990; 141:659-65.

7 Bishop MH, Shoemaker WC, Appel PL, Wo CJ, Zwick C, Kram HB. Relationship between supranormal circulatory values, time delays, and outcome in severely traumatized vatients. Crit Care Med 1993; 21:56-63.

8 Welch HG, Meehan KR, Goodnough LT. Prudent strategies for elective red clood cell transfusion. Ann Intern Med for elective red clood

1992; 116:393-402.

9 Dantzker D. Oxygen delivery and utilization in sepsis. Crit Care Clin 1989; 5:81-98.

10 Dantzker DR. Adequacy of tissue oxygenation. Crit Care Med 1993; 21:S40-S3.

11 Weg JG. Oxygen transport in adult respiratory distress syndrome and other acute circulatory problems: relationship of oxygen delivery and oxygen consumption. Crit Care Med 1991;19:650-7.

12 Grum CM. Tissue oxygenation in low flow states and during hypoxemia. Crit Care Med 1993; 21:S44-S9.

13 Maynard N, Bihari D, Beale R, Smithies M, Baldock G, Mason $R$, et al. Assessment of splanchnic oxygenation by gastric tonometry in patients with acute circulatory failure. ҰAMA 1993;270:1203-10.

14 Couch NP, Dmochowski JR, Van De Water JM, Harken DE, Moore FD. Muscle surface pH as an index of peripheral perfusion in man. Ann Surg 1971; 173:173-83.

15 Van De Water JM, Philips PA, Linton LA, Borst RW, Fisher WR. Muscle surface pH monitoring. Evaluation and clinical application. Arch Surg 1972; 104:799-805.

16 Filler RM, Das JB, Espinosa HM. Clinical experience with continuous muscle $\mathrm{pH}$ monitoring as an index of tissue perfusion and oxygenation and acid-base status. Surgery perfusion and ox

$17 \mathrm{La}$ Gamma EF. Review of clinical implications and applications of neonatal acid-base monitoring during acidosis with tissue pH electodes. In: Lauersen $\mathrm{NH}$, Hockberg HM, eds. Clinical perinatal biochemical monitoring. Baltimore: Williams \& Wilkins, 1981: 229-36.

18 La Gamma EF, Krauss AN, Auld PAM. Tissue surface pH monitoring during reduced blood flow: Metabolic implications and sources of error. $f$ Perinat Med 1982. 10:174-80.

19 Doglio GR, Pusajo JF, Egurrola MA, Bonfigli GC, Parra C, Vetere $L$, et al. Gastric mucosal pH as a prognostic index of mortality in critically ill patients. Crit Care Med 1991; 19:1037-40.

20 Gutierrez G, Palizas F, Doglio G, Wainsztein N, Gallesio A, Pacin J, et al. Gastric intramucosal pH as a therapeutic Pacin J, et al. Gastric intramucosal $\mathrm{pH}$ as a therapeutic index of tissue ox

21 Chang MC, Cheatham ML, Nelson LD, Rutherford EJ, Morris JA Jr. Gastric tonometry supplements information provided by systemic indicators of oxygen transport. $f$ Trauma 1994; 37:488-94.

22 Stockman JA. Anemia of prematurity. Current concepts in the issue of when to transfuse. Pediatr Clin North Am 1986; 33:111-28.

23 Strauss RG, Sacher RA, Blazina JF, Blanchette VS, Schloz LM, Butch SH, et al. Commentary on small-volume red cell transfusions for neonatal patients. Transfusion 1990; 30:565-70.

24 Strauss RG. Transfusion therapy in neonates. $A m \mathcal{F}$ Dis Child 1991; 145:904-11. 
25 Fetus \& Newborn Committee, Canadian Paediatric Society. Guidelines for transfusion of erythrocytes to neonates and premature infants. Can Med Assoc f 1992; 147:1781-6.
26 Waldman S, Krauss AN, Auld PAM. Baroreceptors 26 Waldman S, Krauss AN, Auld PAM. Baroreceptors in preterm infants: their relationship to mat
Dev Med Child Neurol 1979; 21:714-22.

27 Costeloe K, Rolfe P. Continuous limb blood flow estimation in the newborn using electrical impedence plethysmography. Pediatr Res 1980; 14:1053-60.

28 Wu PYK, Wong WH, Guerra G, Miranda R, Godov RR, Preston B, et al. Peripheral blood flow in the neonate. 1 . changes in total, skin, and muscle blood flow with changes in total, skin, and muscle blood flow with

29 Seear M, Wensley D, MacNab A. Oxygen consumptionoxygen delivery relationship in children. $f$ Pediatr 1993; 123:208-14.

30 Mizock BA. Controversies in lactic acidosis implications in critically ill patients. $\mathscr{F} A M A 1987 ; 258: 497-501$.

31 Rackow EC, Astiz ME. Pathophysiology and treatment of septic shock. fAMA 1991; 266:548-54.

32 Hotchkiss RS, Karl IE. Reevaluation of the role of cellular hypoxia and bioenergetic failure in septis. fAMA 1992; 267:1503-10.

33 Ronco J, Fenwick JC, Tweeddale MG, Wiggs BR, Phang PT, Cooper DJ,et al. Identification of the critical oxygen delivery for anaerobic metabolism in critically ill

34 Beal AL, Cerra FB. Multiple organ failure syndrome in the 1990s. FAMA 1994; 271:226-33.

35 Alverson DC, Isken VH, Cohen RS. Effect of booster blood transfusions on oxygen utilization in infants with bronchopulmonary dysplasia. $f$ Pediatr $1988 ; 113: 722-6$.

36 Bifano EM, Smith F, Borer J. Relationship between determinants of oxygen delivery and respiratory abnormalities in preterm infants with anemia. $\mathcal{F}$ Pediatr 1992 ; 120:292-6

37 Lachance C, Chessex P, Fouron JC, Widness JA, Bard H. Myocardial, erythropoietic, and metabolic adaptations to anemia of prematurity. $\mathcal{F}$ Pediatr 1994; 125:278-82.

38 Barr PA, Bailey PE, Sumners J, Cassady G. Relation between arterial blood pressure and blood volume and effect of infused albumin in sick preterm infants. Pediatric 1977; 60:282-9.

39 Lay KS, Bancalari E, Malkus H, Baker R, Strauss J. Acute effects of albumin infusion on blood volume and renal function in premature infants with respiratory distress syndrome. of Pediatr 1980; 97:619-23.

40 Greenough A, Greenall F, Gamsu HR. Immediate effects of albumin infusion in ill premature neonates. Arch Dis Child 1988; 63:307-17.

41 Bignall S, Bailey PC, Bass CA, Cramb R, Rivers RP Wadsworth J. The cardiovascular and oncotic effects of albumin infusion in premature infants. Early Hum Devel 1989; 20:191-201.

42 Emery EF, Greenough A, Gamsu HR. Randomised controlled trial of colloid infusions in hypotensive preterm infants. Arch Dis Child 1992; 67:1185-8.

43 Marik PE, Med M, Sibbald WJ. Effect of stored-blood transfusion on oxygen delivery in patients with sepsis. FAMA 1993; 269:3024-9.

44 Gaudry PL, Duffy C, Joseph D. The pH and titratable acidity of stored CPD blood. Anesthes Intens Care 1980; 8:353-5.

45 Sadidharan $P$, Heimler $R$. Alterations in pulmonary mechanics after transfusion in anemic preterm infants. mechanics after transfusion in
Crit Care Med 1990; 18:1360-2.

46 Morecroft JA, Spitz L, Hamilton PA, Holmes SJ. Necrotizing enterocolitis - multisystem organ failure of the newborn? Acta Paediatr 1994; 396(Suppl):21-3.

47 Adan D, La Gamma EF, Browne LE. Nutritional management and the multisystem organ failure/systemic inflammatory response syndrome in critically ill preterm neonates. Crit Care Clin 1995; 11:751-84.

48 Mortola JP, Frappell PB, Dotta A, Matsuoka T, Fox G, Weeks $\mathrm{S}$, et al. Ventilatory and metabolic responses to acute hyperoxia in newborns. Am Rev Respir Dis 1992; 146:11-15.

49 Russell JA, Phang PT. The oxygen delivery/consumption controversy. Approaches to management of the critically ill. Am $\mathcal{F}$ Respir Crit Care Med 1994; 149:533-7. 